\title{
KAJIAN PENGEMBANGAN MEBEL ROTAN DI SUMBAWA BARAT
}

\author{
Rattan Furniture Development Study in West Sumbawa
}

Edi Eskak

Balai Besar Kerajinan dan Batik, Jl. Kusumanegara No. 7 Yogyakarta, Indonesia

Telp.08562888520, E-mail: eskakedi@gmail.com

Tgl Masuk Naskah: 2 April 2014

Tgl Masuk Revisi: 17 Juni 2014

\begin{abstract}
ABSTRAK
Rotan merupakan hasil hutan yang melimpah di Sumbawa Barat sehingga mempunyai potensi yang besar untuk pengembangan industri mebel rotan. Di Sumbawa Barat saat ini tidak terdapat industri pengolahan rotan asalan menjadi iratan dan pitrit, sebagai bahan anyaman untuk mebel. Tujuan kajian ini adalah untuk mencari solusi pengembangan mebel rotan di Sumbawa Barat yang bahan bakunya masih berupa rotan asalan yaitu berupa rotan batangan menjadi produk mebel. Metode yang digunakan yaitu deskriptif analitis untuk mengkaji objek desain beserta ruang lingkupnya yaitu mebel yang dirancang dari bahan baku rotan batangan. Dari kajian ini dihasilkan kesimpulan bahwa industri mebel rotan di Sumbawa Barat dapat ditumbuhkan dengan pembuatan desain mebel khusus berbahan baku rotan batangan.
\end{abstract}

Kata kunci: pengembangan, mebel rotan batangan, Sumbawa Barat

\section{ABSTRACT}

Rattan is the abundant forest produce in West Sumbawa thus it has a big potential considerably for the development of the rattan furniture industry. Nowadays in West Sumbawa is no rattan processing industry/bars currently into thin strip and pitrit, as for as plaiting materials for furniture. The aim of this study to create furniture designs that explore the rattan material which is still a bullion into furniture products. The method used is a descriptive analysis to describe the design objects those are furniture designed of rattan sticks. From this study is produce insights on a rattan furniture design for rattan sticks industrial development in West Sumbawa, and it can inspire the development of other areas experiencing similar problems.

Keywords: development, rattan furniture, West Sumbawa

\section{PENDAHULUAN}

Rotan secara umum lebih dikenal sebagai bahan untuk kerajinan anyaman dengan berbagai produknya berupa keranjang, tikar, lampit, tas, dan mebel. Namun rotan juga dibuat jembatan, pemukul, tali, bola takraw, mainan anak, dan sebagainya. Rotan merupakan tanaman penting dalam pembuatan alat-alat untuk menunjang aktivitas hidup keseharian sehingga ada peribahasa "tidak ada rotan akarpun berguna". Bahan rotan juga dapat dibuat menjadi produk mebel yang dapat mengikuti perkembangan zaman menjadi mebel mutakhir yang selalu pantas dalam tata interior berbagai gaya dan budaya. Produk rotan memberi kesan alami terhadap interior, sehingga produk dari rotan digemari konsumen baik dari dalam dan luar negeri. Produk rotan berkualitas dari Indonesia banyak diekspor ke berbagai negara.

Sejak abad XVIII Indonesia sudah terkenal sebagai penghasil rotan terbesar di 
dunia yang menguasai $85 \%$ pasar dunia (Rini, 2009). Sisanya 15\% pasok rotan dunia tersebar di banyak negara, seperti: Tiongkok, Filipina, Myanmar, Vietnam, negara-negara Afrika dan Amerika Latin. Negara-negara penghasil rotan lain tersebut rata-rata hanya menghasilkan $2 \%$ dari produksi rotan dunia (Rini, 2009). Beberapa tahun yang lalu, produk rotan Indonesia telah merambah ke berbagai pelosok dunia, seperti Jepang, negara-negara Eropa dan Amerika Serikat, sehingga produk rotan menjadi salah satu sumber penghasil devisa negara yang cukup besar. Dari produk rotan berupa mebel rata-rata setiap tahun menghasilkan devisa sebesar US\$ 310 sampai 325 juta (Maryana, 2009). Di samping itu kegiatan pengolahan rotan dapat menampung banyak tenaga kerja, sejak dari pemungutan rotan di hutan, pembersihan, pengangkutan, perdagangan dan pengolahannya di pabrik mebel, maupun pembuatan mebel pada industri kecil/rumah tangga.

Sumbawa Barat merupakan kabupaten baru hasil pemekaran dari Kabupaten Sumbawa di Provinsi Nusa Tenggara Barat (NTB) berdasarkan Undang-undang No. 30 tahun 2003, tanggal 18 Desember 2003. Visi dari Kabupaten Sumbawa Barat adalah membangun pelayanan publik yang prima dan produktivitas pertanian menuju agroindustri. Untuk mencapai visi tersebut pemerintah kabupaten telah menetapkan misi antara lain: memanfaatkan potensi geografis dan sumber daya alam sesuai dengan daya dukung lingkungan agar tercipta pembangunan yang berkelanjutan. Secara geografis Kabupaten Sumbawa Barat terletak di bagian barat Pulau Sumbawa, berada pada posisi : $9^{\circ} 11^{\circ}-10^{\circ} 20^{\circ} \mathrm{LS}$ dan $118^{\circ} 55^{\circ}-120^{\circ} 23^{\circ}$ BT. Kabupaten Sumbawa Barat merupakan gerbang masuk Pulau Sumbawa melalui pelabuhan Poto Tano.
Kabupaten ini memiliki batas-batas sebagai berikut: sebelah timur berbatasan dengan Kabupaten Bima; sebelah barat berbatasan dengan Lautan Indonesia; sebelah utara berbatasan dengan Kabupaten Sumbawa; sebelah selatan berbatasan dengan Lautan Indonesia. Luas total daerah Sumbawa Barat 1.849.021 Ha, yang terdiri dari 8 Kecamatan (Sumbawa Barat Selayang Pandang, 2013). Secara demografis Sumbawa Barat memiliki jumlah penduduk yang masih sedikit. Berdasarkan survey sosial ekonomi nasional 2009, jumlah penduduk Sumbawa Barat adalah berkisar 105.000 orang, dengan kepadatan penduduk rata-rata 52 orang per $\mathrm{km}^{2}$. Wilayah terpadat adalah kecamatan Taliwang dengan tingkat kepadatan 95 orang per $\mathrm{km}^{2}$. Secara keseluruhan laju pertumbuhan di Sumbawa Barat rata-rata 2,12\%. Meskipun penduduknya termasuk kategori sedikit, namun Sumbawa Barat memiliki potensi sumber daya alam sangat besar, luas hutannya mencapai sekitar $95 \%$ dari luas wilayahnya yang mencapai 1.849.021 Ha, sisanya berbentuk tanah kering $5 \%$ (BPS Kabupaten Sumbawa Barat, 2007).

Eksploitasi tambang emas oleh PT Newmont Nusa Tenggara (PT NNT) sejak tahun 2004 di Sumbawa Barat masih belum memberikan dampak terhadap peningkatan kesejahteraan masyarakat secara menyeluruh. Untuk itu pemerintah perlu mengelola potensi sumber daya alam lainnya untuk meningkatkan kesejahteraan masyarakat. Seiring dengan kebijakan pemerintah pusat melalui Perpres No. 28 tahun 2008 tentang pengembangan industri nasional, yang menekankan pada pengembangan industri daerah berbasis kompetensi inti daerah, pemerintah kabupaten ini telah merencanakan pengembangan industri daerah berbasis komoditas unggulan daerah. Hasil Studi 
Identifikasi Kompetensi Inti Daerah menggunakan metode AHP (Analytic Hierarchy Process) menunjukkan bahwa komoditas unggulan Kabupaten Sumbawa Barat secara berurut adalah: (1) Rotan, (2) Ikan laut, (3) Kelapa, (4) Kambing, dan (5) Sapi. Sedangkan kompetensi inti industrinya adalah kemampuan mengolah rotan menjadi produk kerajinan dan mebel (Kholil, 2009).

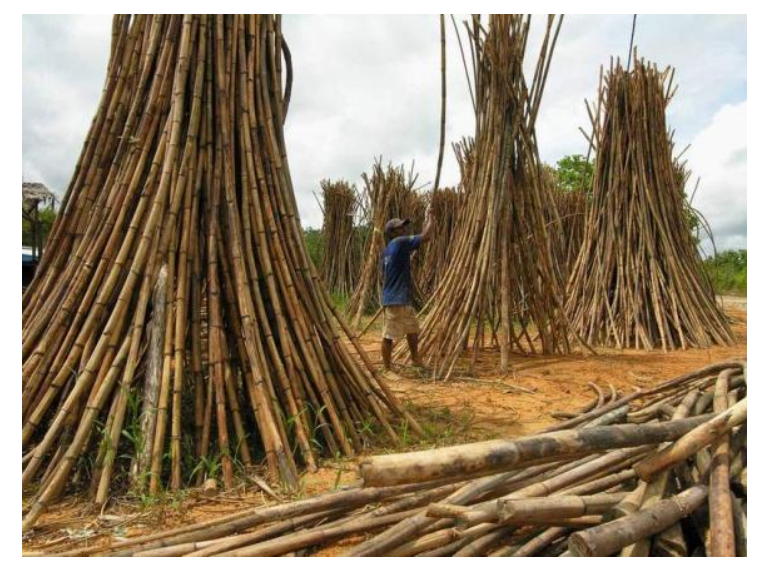

Gambar 1. Rotan asalan/batangan

(Sumber: Yusuf, 2012)

Sumbawa Barat merupakan pendatang baru yang mempunyai potensi rotan alam yang cukup besar untuk pengembangan industri rotan secara berkesinambungan. Menurut Kasie Industri Disperindagkop UMKM Dimas Bayu Fajar Bagaskhara, ST bahwa potensi hutan alam penghasil rotan di Kabupaten Sumbawa Barat mencapai 52.000 hektar (Wawancara, tanggal 25 Oktober 2013). Pada tahun 2013 berhasil dipanen 102 ton rotan asalan, terjadi peningkatan dari tahun sebelumnya yang masih di bawah 100 ton (Kustadi, wawancara, 1 April 2014). Di Sumbawa Barat saat ini belum ada industri pengolahan rotan asalan menjadi iratan dan pitrit, sebagai bahan anyaman untuk mebel. Bahan baku yang tersedia adalah rotan asalan yang masih berbentuk batangan yang diawetkan secara tradisional. Tujuan kajian ini adalah untuk mencari solusi pengembangan mebel rotan di Sumbawa Barat yang bahan bakunya masih berupa rotan asalan yaitu berupa rotan batangan menjadi produk mebel.

\section{METODOLOGI}

Metode yang digunakan yaitu deskriptif analitis untuk mengkaji objek desain dengan berbagai hal yang melingkupinya, yaitu mebel yang dirancang dari bahan baku rotan batangan yang dihasilkan dari hutan Sumbawa Barat.

\section{PEMBAHASAN}

Produk mebel rotan merupakan komoditas yang prospektif. Mebel rotan dibutuhkan manusia masa kini sebagai salah satu pilihan perabot dalam menunjang aktivitas hidup sehari-hari. Mebel dapat berupa kursi, meja, pembatas ruang, rak, dan aksesoris pendukungnya misalnya tempat majalah, bingkai kaca cermin, kap lampu, dan lain sebagainya. Produk rotan dapat beradaptasi dengan dinamika desain modern tetapi masih tetap memperlihatkan kesan alami sehingga dapat ditempatkan sesuai dengan tema dan gaya interior yang diinginkan.

Sebagai bahan alami, rotan mempunyai keunggulan fisik dan artistik yang unik, sehingga mebel rotan disukai banyak konsumen baik dalam maupun luar negeri. Prospek ekonomi yang cukup menjanjikan kesejahteraan, bila masyarakat mau dan mampu memanfaatkan rotan menjadi produk-produk yang mempunyai nilai manfaat. Produk yang mempunyai nilai manfaat dapat menjadi komoditas perdagangan yang menghasilkan banyak uang. Regulasi pelarangan ekspor rotan mentah tahun 2012 lalu, berdasarkan Peraturan Menteri Perdagangan yaitu No. 35/M-DAG/PER/11/2011 tentang Kebijakan Ekspor Rotan dan Produk Rotan, 
Permendag No. 36/M-DAG/PER/11/2011 tentang Pengangkutan Rotan Antar Pulau, menjadikan para pengusaha rotan Sumbawa Barat tidak bisa mengekspor bahan rotan mentah (Anta, 2013). Penjualan rotan mentah secara langsung hanya menciptakan lapangan kerja sempit yaitu sebatas aktivitas produktif para pemanen dan pedagangnya. Bila rotan diolah sampai menjadi produk jadi, maka sumber daya alam ini dapat menjadi sarana terciptanya lapangan kerja yang lebih luas sehingga dapat menyejahterakan masyarakat secara lebih luas juga. Nilai jual rotan pun ikut naik karena telah diolah menjadi berbagai produk yang mempunyai nilai jual lebih tinggi dibandingkan dengan menjual rotan asalan maupun rotan olahan setengah jadi.

Secara tradisional rotan di Sumbawa Barat telah dibuat menjadi barang-barang untuk mendukung aktivitas sehari-hari antara lain yaitu berupa keranjang, pecut, pemukul, perisai, anyaman dan aneka wadah. Produk tradisional ini mempunyai pasar yang terbatas. Industri rotan Sumbawa Barat pernah mengalami kejayaan pada tahun 1970-an sampai tahun 1980-an dengan pemasaran produknya ke berbagai daerah di Jawa dan daerah-daerah lainnya, namun kemudian mengalami kemunduran karena kalah teknologi dan kekurangan modal (Billah, 2009).

Fokus pengembangan mebel dalam kajian ini karena produk ini lebih dibutuhkan masyarakat yaitu sebagai perabotan untuk menunjang aktivitas hidup sehari-hari, sehingga produk yang dihasilkan akan lebih laku, karena memang dibutuhkan banyak orang. Perabotan yang dibutuhkan seperti kursi, meja, partisi, mainan anak dan sebagainya disebut mebel. Mebel merupakan perabotan yang memiliki tempat untuk menyimpan sesuatu dengan posisi tetap atau memiliki tempat tertentu di dalam ruangan yang berdiri sendiri. Dari segi fungsi mebel terdiri dari empat jenis yaitu tempat menyimpan sesuatu di atasnya, tempat menyimpan sesuatu di dalamnya, tempat terlentang atau tidur, dan tempat duduk (Jamaludin, 2007).

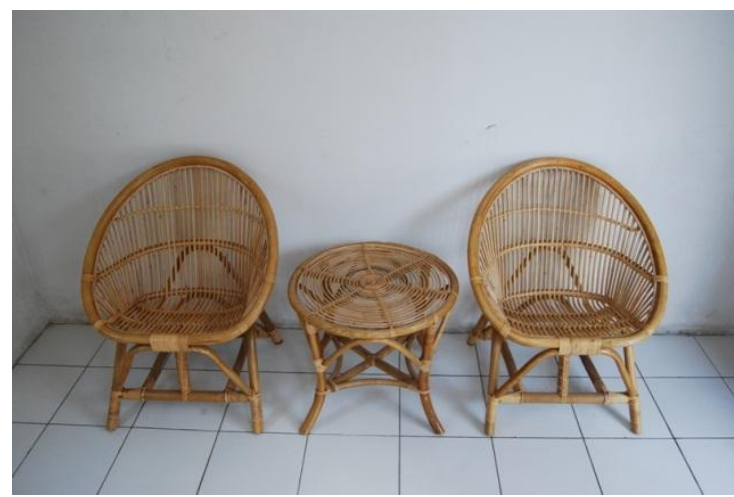

Gambar 2. Kursi teras rotan non anyaman (Sumber: Iwan, 2013)

\section{Karakteristik Rotan}

Rotan adalah tanaman sejenis palm yang merambat dan dapat tumbuh panjang mencapai 100 meter lebih (Soedjono, 2008). Tanaman rotan tumbuh merambat pada pohon induk. Jenis-jenis rotan yang ada di Sumbawa Barat yaitu rotan getah, rotan umbul, dan rotan epek (Sanusi, 2012). Rotan getah termasuk dalam jenis rotan yang paling bernilai komersil baik ekspor maupun dalam negeri (Kasmudjo, 2013).

Secara umum rotan memiliki karakteristik kaku tetapi elastis dan kuat. Rotan merupakan substrat yang pejal, kuat, dan ulet, sehingga dapat dibentuk lengkung, dipilin, dan dianyam. Untuk batang rotan yang berdiameter besar, cara pengolahannya dapat dipanaskan sambil dibentuk dengan mal (Iensufiie, 2008). Rotan dijadikan bahan baku mebel karena kekuatan rotan dari sifat fisik yang baik. Sifat fisik rotan merupakan sifat khas yang dimiliki oleh suatu jenis rotan secara alamiah. Sebagai bahan alami, rotan sudah sejak lama dikenal oleh masyarakat Indonesia dan dapat digunakan 
dalam berbagai keperluan hidup sehari-hari, bahkan di beberapa tempat rotan telah menjadi pendukung perkembangan budaya dan perekonomian setempat. Dengan semakin berkembangnya zaman, ide-ide dan kreativitas pun berkembang. Hal ini berdampak dalam desain mebel dan kerajinan rotan pun ikut berkembang juga.

Warna dan kilap pada batang rotan bervariasi pada jenis rotan yang berbeda maupun yang sama. Dalam perdagangan, warna pada batang rotan sangat berperan penting, makin baik warnanya maka makin mahal harganya. Warna pada batang rotan yang muda berbeda dengan batang yang tua. Begitu pula warna pada pangkal rotan berbeda dengan warna pada bagian tengah dan ujungnya. Warna yang baik pada rotan adalah batang rotan yang berwarna hijau daun pada saat masih hidup. Kilap merupakan sifat batang rotan untuk memantulkan cahaya. Rotan yang berkilap atau suram dapat memberikan ciri yang khusus dari suatu jenis rotan dan dapat menambah keindahan dari rotan itu sendiri. Kilap rotan dipengaruhi oleh kandungan air dalam rotan. Makin tinggi kadar air, kilap batang rotan akan makin suram. Adanya zatzat yang mengandung lemak dan berminyak akan mengurangi kilap rotan (Januminro, 2000).

Rotan merupakan material alami yang relatif ringan. Hal ini merupakan keuntungan saat pengangkutan, mebel rotan relatif ringan dibanding bobot mebel kayu. Berat pada rotan disebabkan oleh kandungan zat air dalam batangnya. Cara mengurangi berat pada rotan dapat dilakukan dengan pengeringan (Jamaludin, 2013).

Kekerasan dan elastisitas pada rotan menunjukkan ketahanan rotan pada tekanan dan gaya tertentu. Tingkat kekerasan dan elastisitas sangat dipengaruhi oleh kadar air, umur rotan saat dipungut, dan posisi batang rotan yang digunakan. Makin rendah kadar air pada rotan, makin tinggi tingkat kekerasan dan elastisitasnya. Makin tua umur rotan yang dipungut akan makin baik, dan posisi rotan yang makin ke pangkal batang juga akan semakin baik (Januminro, 2000).

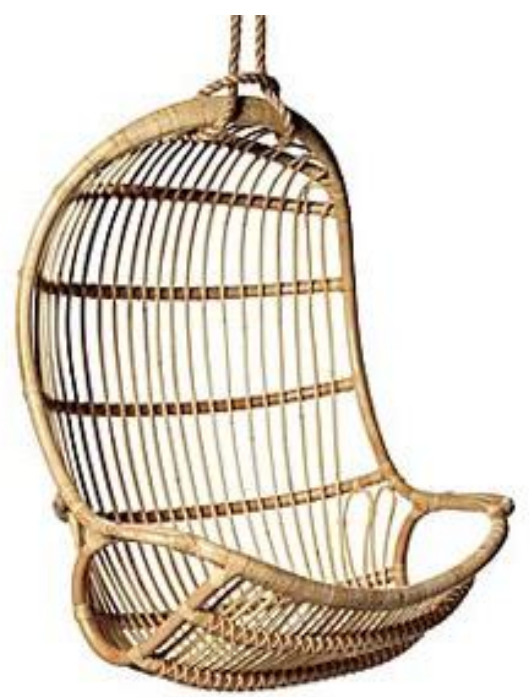

Gambar 3. Kursi ayunan anak yang dibuat dengan memanfaatkan sifat elastis rotan

(Sumber: Serena, 2013)

Besar kecilnya diameter rotan sangat berpengaruh pada tujuan penggunaannya. Rotan yang diameternya besar biasanya digunakan untuk konstruksi mebel, sedangkan yang diameter kecil digunakan untuk pengikat dan anyaman. Selain sifat fisiknya, rotan juga memiliki sifat mekanik yang merupakan sifat rotan dalam menahan kekuatan dari luar. Sifat ini dapat menjadikan rotan berubah bentuk dan ukuran (Januminro, 2000).

Keteguhan tekan pada rotan adalah daya tahan rotan terhadap tekanan yang dapat menghancurkannya. Sifat kekakuan rotan merupakan kekuatan rotan dalam mempertahankan bentuknya. Sedangkan keuletan rotan adalah kemampuan rotan untuk menahan kekuatan yang terjadi secara 
mendadak dalam waktu yang singkat. Rotan yang digunakan untuk rangka mebel, biasanya yang memiliki sifat ulet (Januminro, 2000).

Keteguhan tarik merupakan daya tahan rotan terhadap kekuatan yang dapat memisahkan bagian-bagian rotan. Jika keteguhan tarik pada sebuah rotan tinggi, maka rotan tersebut akan baik, kuat, dan awet. Bilamana rotan pecah akan memiliki kecenderungan untuk membelah ke arah serat karena rotan berserat lurus dan panjang. Oleh karena itu, rotan lebih mudah pecah ke arah radial sebagaimana bahan bambu (Eskak, 2012). Namun justru inilah yang menjadikan rotan dapat diirat untuk bahan anyaman.

Dalam perdagangan dikenal nama-nama yang baku dari rotan yaitu: rattan, binrattan, canes dan corepeel. Rattan dan binrattan merupakan istilah umum (ilmiah dan perdagangan) untuk jenis rotan bulat dan belum diolah. Canes merupakan istilah untuk rotan belahan, iratan atau anyaman. Corepeel merupakan istilah untuk jenis rotan hati atau pitrit, yaitu rotan yang telah dibelah dan dikupas kulitnya. Produk berupa canes dan corepeel dimaksudkan untuk menambah dan meningkatkan daya guna rotan (Kasmudjo, 2010). Nama-nama ini berdasarkan pada tempat atau negara tujuan ekspor, sedangkan secara bentuk rotan yang diperdagangkan umumnya dapat berupa: (1) Rotan asalan yaitu rotan bulat mentah yang belum diberikan perlakuan apapun, (2) Rotan W/S yaitu rotan bulat yang telah diberikan perlakuan pencucian/washed dan pengasapan dengan belerang/sulfurization, sehingga lebih berwarna muda dan kompak merata, (3) Rotan setengah jadi yaitu produk rotan awal proses berupa iratan/belahan, rotan polis, rotan hati/core, rotan kupasan dan sebagainya, (4) Rotan jadi yaitu produk rotan yang telah diproses lengkap sehingga menghasilkan barang-barang dari rotan yang telah siap pakai seperti: anyaman, tikar/lampit, kipas, tas rotan, keranjang, aneka mebel dan sebagainya (Kasmudjo, 2011).

\section{Mebel Rotan}

Mebel biasa disebut juga furnitur merupakan alat atau perabot penunjang yang diperlukan manusia untuk aktivitas kehidupan sehari-hari. Mebel adalah perabotan yang memiliki fungsi, yaitu digunakan untuk aktivitas manusia dan atau tempat untuk menyimpan sesuatu dengan posisi tetap atau memiliki tempat tertentu di dalam ruangan yang berdiri sendiri. Kata mebel berasal dari bahasa Prancis meubel, atau bahasa Jerman mobel, sedangkan furnitur berasal dari bahasa Inggris furniture. Kedua istilah itu mempunyai arti yang sama yaitu benda pakai yang dapat dipindahkan, berguna bagi kegiatan hidup manusia, mulai dari duduk, tidur, bekerja, makan, bermain dan sebagainya, yang memberi kenyamanan dan keindahan bagi para pemakainya (Marizar, 2005).

Rotan batangan bahan untuk mebel perlu diawetkan terlebih dahulu. Rotan yang sudah siap diproses kemudian dipotongpotong sesuai dengan ukuran yang diinginkan dengan menggunakan gergaji. Proses selanjutnya adalah pembengkokan. Alat yang diperlukan untuk membengkokkan rotan adalah tandan pembengkok, kompor gas/sembur api, dan steaming. Ada beberapa kerusakan pada proses pembengkokan, seperti pecah, patah dan putusnya serat pada bagian permukaan yang dilengkungkan. Kemudian dilakukan perakitan kombinasi rotan batangan besar untuk rangka dan rotan kecil untuk isian. Pada bagian sambungan mebel, agar lebih rapi dan semakin kuat maka ditali dan dibalut dengan iratan kulit rotan. Langkah 
akhir dalam proses ini adalah finishing. Finishing dapat berupa penggosokan, pembersihan, pemberian warna, pelapisan cat/coating dan pemberian aksesoris pelengkap, misalnya jok busa dan sebagainya (Manurung, 2013).

Dengan konstruksi yang baik, mebel rotan dapat bertahan lama atau awet. Konstruksi mebel rotan pada umumnya berupa bentuk yang dilengkungkan dan sistem sambungan. Beberapa sambungan rotan yang biasa dipakai dalam konstruksi mebel adalah sambungan lurus, sambungan silang, sambungan sudut, dan sambungan siku T (Soedjono, 1999), seperti yang terlihat dalam Gambar 4.
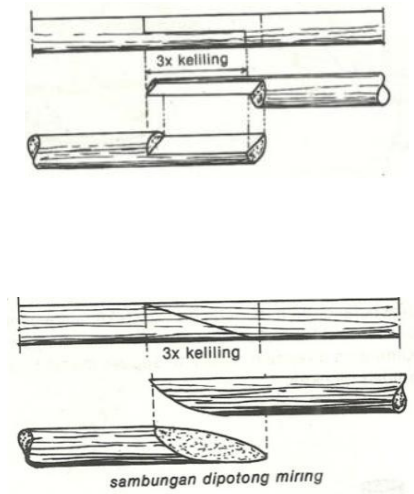

(a)
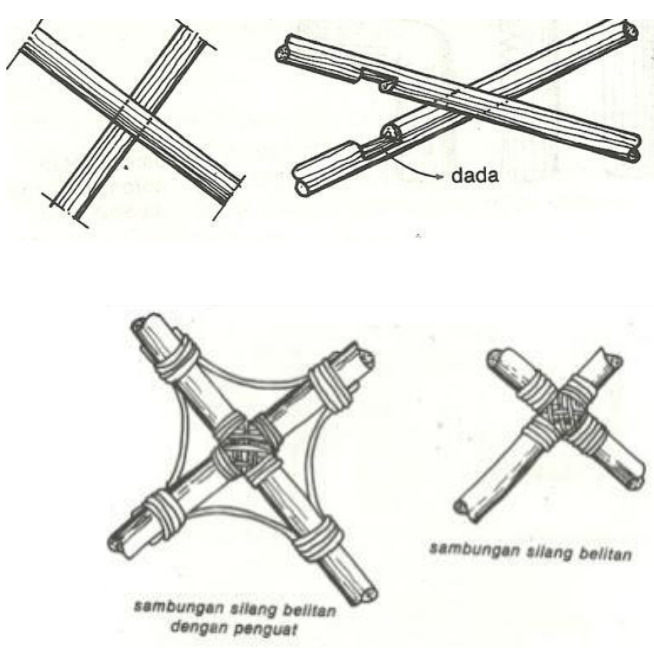

(b)
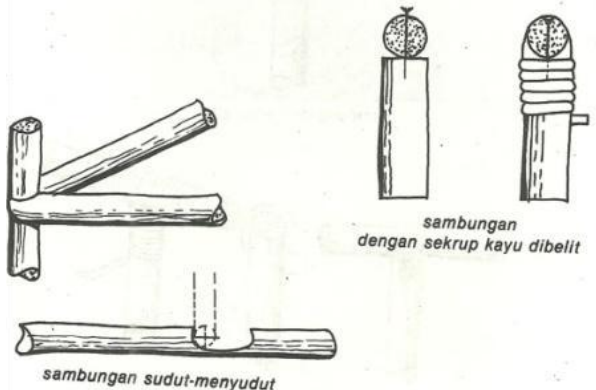

(c)

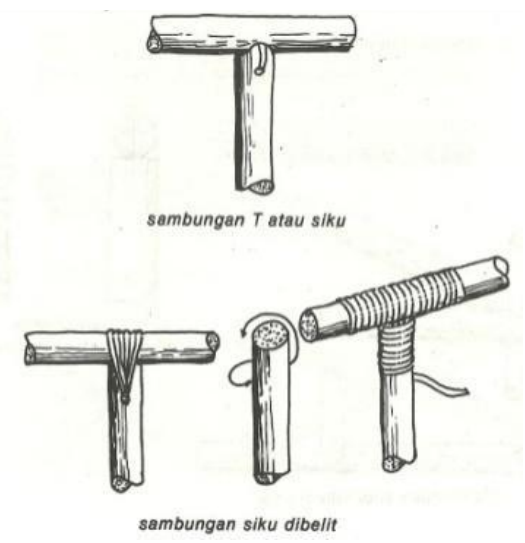

(d)

Gambar 4. (a) Sambungan lurus

(b) Sambungan silang

(c) Sambungan sudut

(d) Sambungan $\mathrm{T}$ atau siku

Kekurangan dari mebel rotan batangan adalah tidak sekuat mebel dari rotan yang dianyam, karena anyaman ikut memperkuat konstruksi sambungan. Teknik anyaman pada rotan juga lebih memungkinkan untuk diversifikasi desain mebel dan kerajinan rotan secara lebih luas. Untuk itu pemerintah Kabupaten Sumbawa Barat hendaknya segera membangun pabrik pengolahan rotan berskala besar untuk mendukung dan mempercepat kemajuan industri kerajinan rotan. 


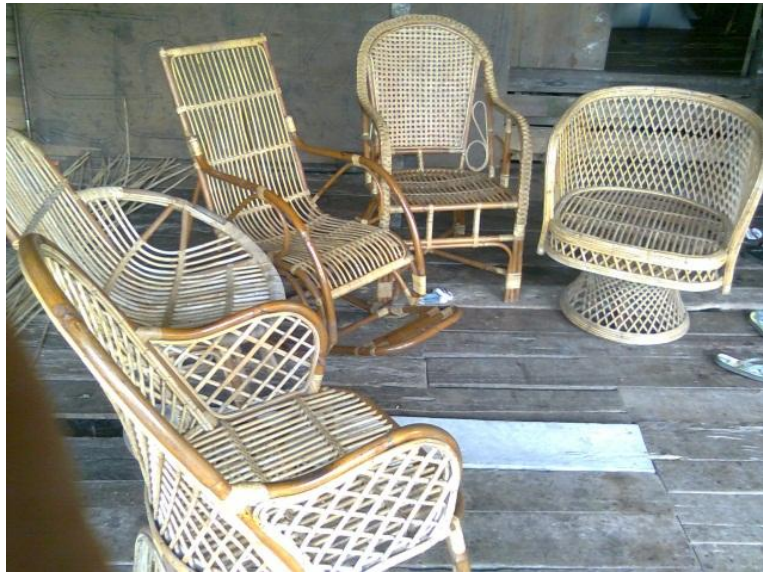

Gambar 5. Anekan kursi dari rotan bulat

(Sumber: Taufik, 2012)

Finishing pada produk rotan berfungsi untuk memperindah dan melindungi permukaan perabot rotan dari berbagai pengaruh dari luar (cuaca, jamur, serangga perusak, gesekan, dan sebagainya) yang bisa merusak rotan. Proses finishing pada rotan tidak jauh berbeda dengan proses finishing pada kayu (Yuswanto, 1999). Hal yang perlu diperhatikan yaitu membersihkan permukaannya dari debu, minyak, wax, dan mengurangi kandungan air pada bahan rotan dengan cara pemanasan. Setelah menjadi mebel rotan dicat atau di-coating dengan lacquer untuk menambah keindahan (Iensufiie, 2008). Namun sebelumnya bulubulu halus rotan harus dibakar cepat/sekilas (Jawa: dibrongot) agar hasil pengecatan nantinya halus, bersih, dan optimal.

Teknologi finishing mebel rotan selalu berkembang sehingga saat ada beberapa teknik yang dapat dilakukan, antara lain dengan cara: (a) Natural Coating yaitu mebel rotan diamplas halus dan diberi sanding sealer lalu diberi cat transparan, hal ini membuat serat-serat rotan tampak lebih alami, warna rotan pun akan muncul dengan kesan natural, (b) Stain yaitu membuat mebel rotan terlihat berwarna gelap seperti coklat tua, (c) Fancy Colour adalah pengecatan rotan yang menciptakan efek unik pada finishing yaitu penuh warnawarni muda menyala tapi terlihat temaram, (d) Water Based Glaze adalah pewarna yang memberikan kesan tua/klasik (Marizar, 2007).

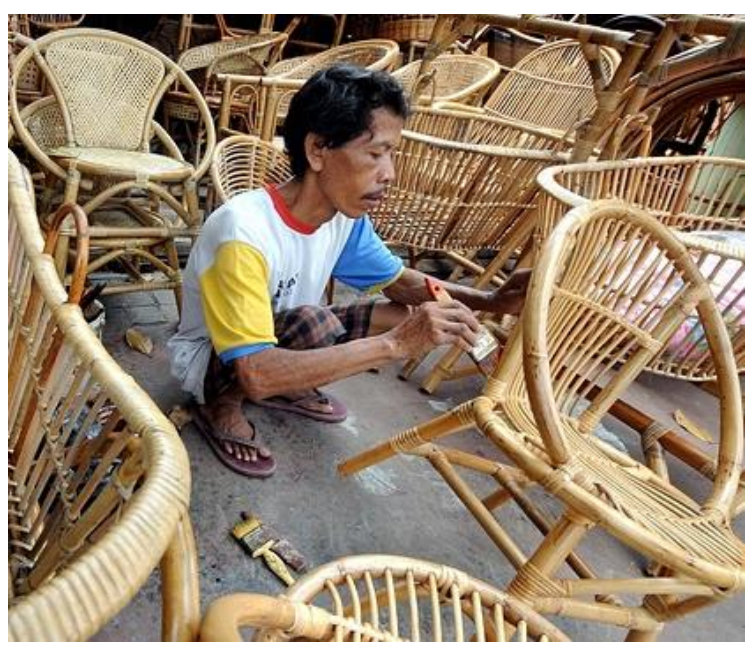

Gambar 6. Finishing mebel rotan

(Sumber: Sari, 2013)

\section{Evaluasi Pelatihan Mebel Rotan}

Pada tanggal 21 sampai 25 Oktober 2013 di Kota Taliwang, Sumbawa Barat diadakan pelatihan mebel dan kerajinan rotan oleh Disperindagkop UMKM Kabupaten Sumbawa Barat yang didukung oleh Disperindagkop Provinsi NTB dengan mendatangkan instruktur dari Balai Besar Kerajinan dan Batik (BBKB) Yogyakarta. Pelatihan ini bertujuan untuk meningkatkan keterampilan 20 orang perajin rotan Sumbawa Barat. Dalam pelatihan diajarkan peningkatan kualitas dan diversifikasi desain pembuatan mebel dan kerajinan. Kendala yang dihadapi adalah rotan setengah jadi untuk bahan mebel dan kerajinan harus didatangkan dari Kota Mataram, Pulau Lombok, sehingga harganya menjadi lebih mahal. Padahal rotan mentah di Sumbawa Barat melimpah, oleh karena itu pemerintah daerah sebaiknya segera membangun pabrik pengolahan rotan 
di Sumbawa Barat untuk mengolah rotan dari hasil hutan daerah sendiri.
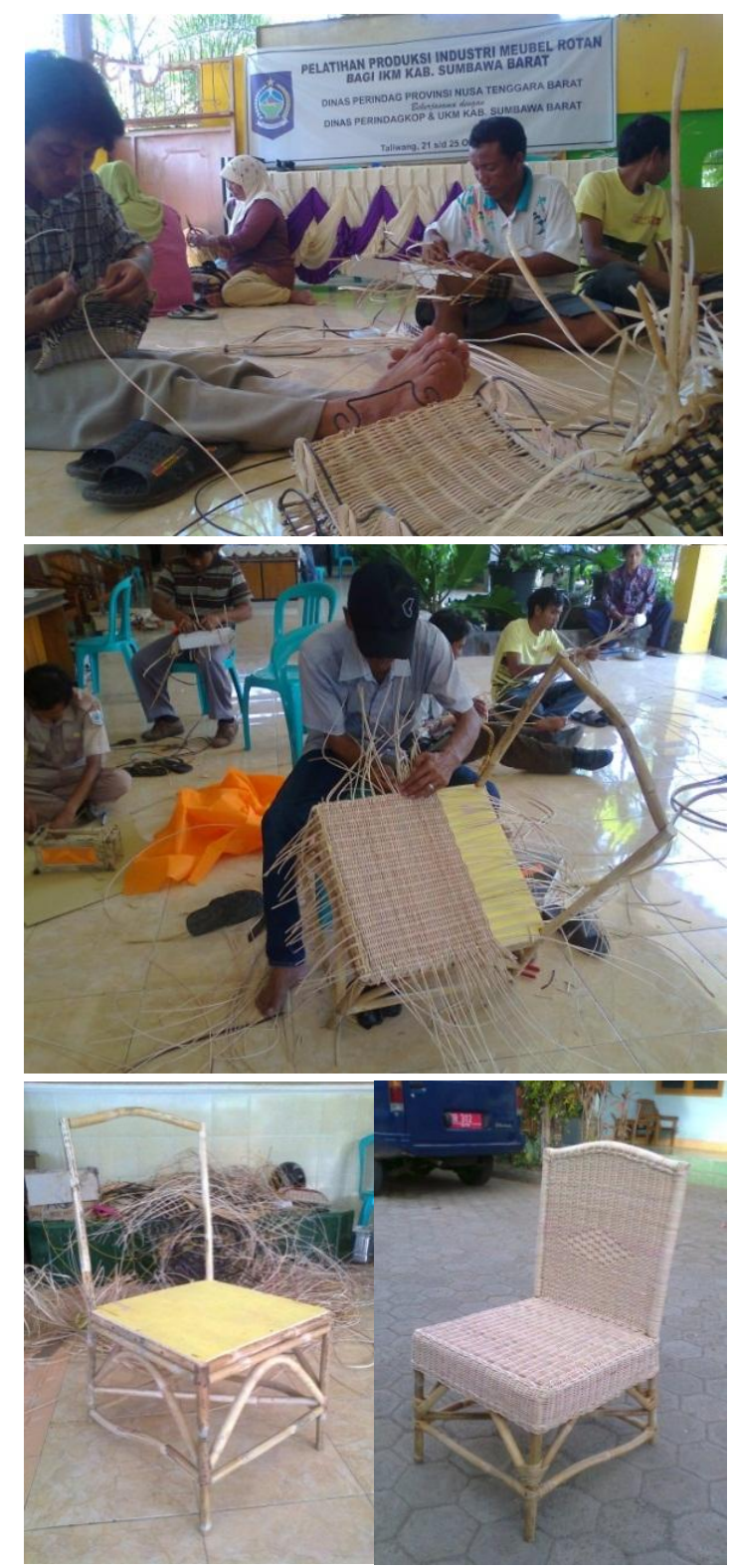

Gambar 7. Pelatihan produksi industri mebel rotan bagi IKM di Sumbawa Barat,

21-25 Oktober 2013

(Foto: Edi Eskak, 2013)

Pemasaran hasil produksi rotan juga masih terkendala, sehingga perajin kurang bergairah dalam berproduksi. Pemerintah daerah hendaknya membuat kebijakan agar hasil produksi perajin terserap juga oleh pasar lokal, seperti mewajibkan kantor instansi, sekolah, hotel, restoran dan sebagainya untuk memakai produk mebel rotan asli Sumbawa Barat. Pemasaran ke luar daerah maupun ekspor juga perlu ditingkatkan dengan promosi lebih gencar dan terprogram. Pelatihan untuk perajin juga perlu senantiasa dilakukan untuk meningkatkan keterampilan dan wawasan kewirausahaan. Pengiriman magang perajin ke sentra industri rotan di Cirebon untuk meningkatkan skill dan studi banding juga perlu dilakukan secara terprogram dan berkelanjutan. Keberadaan perusahaan, bank, BUMN, BUMD, di Sumbawa Barat juga bisa dilibatkan peran aktifnya sebagai konsumen dan juga "bapak angkat" yang membina dan memajukan dari industri rotan tersebut. Pembangunan ruang pameran bersama juga perlu dibangun di sentra IKM rotan Sumbawa Barat.

\section{KESIMPULAN DAN SARAN Kesimpulan}

Rotan merupakan hasil hutan yang melimpah di Sumbawa Barat, sehingga industri mebel rotan di sana mempunyai prospek yang cerah. Pengembangan industri mebel rotan terkendala karena belum adanya industri pengolahan rotan mentah menjadi bahan baku siap pakai. Oleh karena itu pengembangan industri mebelnya perlu diarahkan terlebih dahulu untuk mengeksplorasi rotan batangan menjadi aneka produk mebel. Dengan desain dan teknologi yang tepat, bahan rotan batangan dapat dibuat menjadi aneka perabot mebel yang berkualitas. Dari kajian ini dihasilkan kesimpulan bahwa industri mebel rotan di Sumbawa Barat dapat ditumbuhkan dengan pembuatan desain mebel khusus berbahan baku rotan batangan.

\section{Saran}

Pembinaan kualitas dan kuantitas produksi mebel rotan Sumbawa Barat perlu ditingkatkan secara terprogram dan 
berkelanjutan oleh dinas terkait. Promosi dan pemasaran juga secara intensif perlu dilakukan untuk mempercepat kemajuan industri mebel rotan ini. Pembangunan pabrik untuk pengolahan rotan asalan menjadi bahan baku kerajinan dan mebel perlu segera dilakukan untuk mendukung industri kerajinan dan mebel rotan di Sumbawa Barat.

\section{DAFTAR PUSTAKA}

Anta. 2013. Larangan Ekspor Rotan Buka Pintu Investasi. (http://www.hukumonline.com/berit a/baca/lt511cafe6d4195/laranganekspor-rotan-buka-pintu-investasi, diakses 30 Maret 2014).

Bagaskhara, D.B.F. 2013. Wawancara tanggal 25 Oktober 2013 di Taliwang, Sumbawa Barat.

Billah. 2009. Potensi Daerah Sumbawa. (http://blogerssumbawa.blogspot.c om/2009/09/potensi-daerah.html, diakses 18 Oktober 2013).

BPS Kabupaten Sumbawa Barat. 2007. Sumbawa Barat Dalam Angka, Taliwang: Badan Pusat Statistik Kab Sumbawa Barat.

Eskak, E. dan Harnandito P. 2012. Teknologi Ukir Krawangan pada Bambu Betung (Dendrocalamus asper). Dinamika Kerajinan dan Batik, Vol. 31, No. 1.

Iensufi, T. 2002. Furniture \& Handicraft Berkualitas Ekspor. Jakarta: Erlangga.

Iwan. 2013. Kursi Teras Rotan. (http://www.bdsrattan.com/foto_pr oduk/68DSC_3107x.jpg, diakses 17 Oktober 2013).

Jamaludin, 2007. Pengantar Desain Mebel. Bandung: Kiblat Buku Utama.

Jamaludin, Detty, F., dan Adani, I. 2013. Desain Kursi Berbahan Baku Rotan dari Masa ke Masa. Jurnal Rekajiva. No. 01, Vol. 01.

Januminro, C.F.M. 2000. Rotan Indonesia. Yogyakarta: Kanisius.

Kasmudjo. 2010. Teknologi Hasil Hutan Suatu Pengantar. Yogyakarta: Cakrawala Media.

Kasmudjo. 2011. Hasil Hutan Non Kayu. Yogyakarta: Cakrawala Media.

Kasmudjo. 2013. Rotan dan Bambu. Yogyakarta: Cakrawala Media.

Kholil. 2009. Pengembangan Kompetensi Inti Industri Daerah Berbasis Potensi Unggulan Sumber Daya Alam Lokal. Studi Kasus di Kabupaten Sumbawa Barat (http://portal.kopertis3.or.id/handle /123456789/1509, diakses 17 Oktober 2013).

Kustadi, A.D. 2013. Wawancara tanggal 1 April $2014 \quad$ melalui https://www.facebook.com.

Manurung, J. 2013. Rotan Peluang Bisnis. (http://jordymanurung.blogspot.co m/2013/04/rotan-calamusmananpeluang-bisnis.html, diakses 31 Maret 2014).

Marizar, S. E. 2005. Design Furniture. Yogyakarta: Media Pressindo.

Marizar, S. E. 2007. Serial Rumah: Rotan dan Material Unik. Jakarta: Gramedia.

Maryana, I. 2009. Rotan Hasil Primadona Hutan Non Kayu. (http://www.rotanindonesia.org/ind ex.php/kajian-tulisan/25-rotan/81rotan-primadona-hasil-hutan-nonkayu, diakses 29 Maret 2014).

Rini, M.N. 2009. Masalah Pemasaran Rotan.

(http://www.rotanindonesia.org/ind ex.php/kajian-tulisan/25-rotan/80masalah-pemasaran-rotan, diakses 29 Maret 2014). 
Sanusi, D. 2012. Kekayaan Belantara Indonesia. Surabaya: Penerbit Brilian Internasional.

Sari, D. dan Ivansyah. Ragam Gaya Rotan. (http://www.tempo.co/read/news/20 13/07/24/108499416/Ragam-GayaRotan, diakses 31 Maret 2014).

Serena and Lily. 2013. Kids Seating Poufs Hanging Rattan Chair. (http://www.serenaandlily.com/Kid s/Kids-Seating-Poufs-Hanging-

Rattan-

Chair?utm_campaign=type $1 \&$ utm _medium=HardPin\&utm_source= Pinterest, diakses 17 Oktober 2013).

Soedjono. 1999. Berkreasi Dengan Rotan. Bandung: Remaja Rosadakarya.

Soedjono, dan Srinuryani, E. 2008. Kerajinan Rotan. Bandung: Angkasa.
Sumbawa Barat Selayang Pandang. 2013. (http://www.sumbawabaratkab.go.i $d / x 9 /$, diakses 18 Oktober 2013).

Taufik, A. 2012. Aneka Jenis Kursi Rotan. (http://rumahidaman87.blogspot.co m/2012/12/aneka-jenis-kursirotan.html, diakses 18 Oktober 2013).

Yusuf, H. 2012. Pengusaha Rotan Usulkan Sistim Buffer Stock Kemdag Beri Lampu Hijau. (http://suarapengusaha.com/2012/0 9/08/pengusaha-rotan-usulkansistim-buffer-stock-kemdag-berilampu-hijau/rotan/, diakses 30 Maret 2014).

Yuswanto. 1999. Finishing Кауи. Yogyakarta: Kanisius. 
64 Dinamika Kerajinan dan Batik, Vol.31, No.1, Juni 2014 